Bangladesh J. Zool. 41(2): 199-206, 2013

\title{
GROWTH AND DEVELOPMENT OF THE MULBERRY SILKWORM, BOMBYX MORI L. ON VITAMIN B AND C SUPPLEMENTED DIET
}

\author{
Md. Kamrul Ahsan*, Ataur Rahman Khan and Tasnima Ferdous \\ Department of Zoology, Rajshahi University, Rajshahi-6205, Bangladesh
}

\begin{abstract}
The effect of vitamin B and vitamin C on the growth and development of Bombyx mori L. has been studied. Oral supplementation of different concentrations of vitamin $\mathrm{B}$ and $\mathrm{C}$ to the $3^{\text {rd }}$, $4^{\text {th }}$ and $5^{\text {th }}$ instar larvae of multivoltine silkworm variety, BSR-95/14(M) resulted significant increase in larval and pupal characters. It was observed that the development of larvae and pupae took place up to a particular dose. There was also a significant increment in the various growth indices following vitamin supplements with the mulberry leaves.
\end{abstract}

Key words: Growth, development, vitamin, silkworm, Bombyx mori L.

\section{INTRODUCTION}

Feeding of nutritionally enriched leaves showed better growth and development of silkworms as well as improve the economic value of cocoons (Krishnaswami et al. 1971). The influence of micronutrients on larval development and cocoon characters of silkworm were also studied (Vishwanath and Krishnamurthy 1983). Fortification of mulberry leaves with supplementary compounds to increase the larval growth and development has been carried out. These include vitamins (Saha and Khan 1996, Nirwani and Kaliwal 1996, Nirwani et al. 1998, Etebari et al. 2004, Rahmathulla et al. 2007); hormones (Magadum et al. 1992, Trivedy et al. 1993, Saha and Khan 1997); amino acid (Khan and Faruki 1990, Qadar et al. 1994, Saha et al. 1994, Saha and Khan 1997); and minerals (Magadum et al. 1992, Islam and Khan 1993, Khan and Saha 1995). Nutritional background of the larval stage significantly influences the status of the resulting larva, pupa and fibre (Ahmed et al. 1998, Rahmathulla et al. 2002, Khan and Saha 2003, Etebari and Matindoost 2004). Although the mulberry leaves are the complete diet for silkworm, sometimes dietary deficiencies occur due to different factors.

Vitamins are a group of unrelated organic compounds needed only in minute quantities in the diet that are essential for specific metabolic reactions within the cell and necessary for normal growth and maintenance of health. It prevents associated deficiency diseases. Dosages of vitamins are very determinative for normal growth of silkworm. Etebari et al. (2004) reported yield decrease when

${ }^{*}$ Corresponding author. 
the ascorbic acid concentration was enhanced in the silkworm diet. Similar effects of multivitamins on the silkworm have been confirmed by Saha and Khan (1996), and Etebari and Matindoost (2004). However, it has been reported that dietary supplementation of vitamins and minerals produced a significant increment in the growth and development of B. mori (Saha and Khan 1996).

The following investigation was undertaken to determine the effects of vitamin $\mathrm{B}$ and $\mathrm{C}$ supplementation with the diet on the growth and development of silkworm, B. mori.

\section{MATERIAL AND METHODS}

Experimental animal and rearing: The eggs of silkworm variety, BSR 95/14(M) were obtained from the Germplasm Bank, Bangladesh Sericulture Research and Training Institute, Rajshahi and reared in the Sericulture Laboratory, Department of Zoology, University of Rajshahi, following the scientific silkworm rearing techniques (Krishnaswami 1978, Rahman 1983). After disinfection and incubation of eggs; the larvae that hatched out were reared up to the second instar on fresh mulberry leaves (Morus alba L.). Third instar larvae were divided into seventeen experimental groups including the control. Each group consisted of three replications, each of 70 worms. The experiment was conducted at $28 \pm 2{ }^{\circ} \mathrm{C}$ and a relative humidity of $75.00 \pm 6 \%$.

Treatments: Vitamin B (Opsovit ${ }^{\circledR}$ ) and Vitamin C (Ceevit) were purchased from local market and various concentrations were prepared by mixing the requisite amounts of vitamins in distilled water.

The concentrations of the vitamins used were as follows: $\mathrm{T}_{0}=$ Control, $\mathrm{T}_{1}=$ $2.9 \% \mathrm{~B}+25 \% \mathrm{C}, \mathrm{T}_{2}=5.8 \% \mathrm{~B}+25 \% \mathrm{C}, \mathrm{T}_{3}=8.7 \% \mathrm{~B}+25 \% \mathrm{C}, \mathrm{T}_{4}=11.6 \% \mathrm{~B}+$ $25 \% \mathrm{C}, \mathrm{T}_{5}=2.9 \% \mathrm{~B}+12.5 \% \mathrm{C}, \mathrm{T}_{6}=5.8 \% \mathrm{~B}+12.5 \% \mathrm{C}, \mathrm{T}_{7}=8.7 \% \mathrm{~B}+12.5 \% \mathrm{C}, \mathrm{T}_{8}$ $=11.6 \% \mathrm{~B}+12.5 \% \mathrm{C}, \mathrm{T}_{9}=2.9 \% \mathrm{~B}+6.25 \% \mathrm{C}, \mathrm{T}_{10}=5.8 \% \mathrm{~B}+6.25 \% \mathrm{C}, \mathrm{T}_{11}=8.7 \%$ $\mathrm{B}+6.25 \% \mathrm{C}, \mathrm{T}_{12}=11.6 \% \mathrm{~B}+6.25 \% \mathrm{C}, \mathrm{T}_{13}=2.9 \% \mathrm{~B}+3.125 \% \mathrm{C}, \mathrm{T}_{14}=5.8 \% \mathrm{~B}+$ $3.125 \% \mathrm{C}, \mathrm{T}_{15}=8.7 \% \mathrm{~B}+3.125 \% \mathrm{C}, \mathrm{T}_{16}=11.6 \% \mathrm{~B}+3.125 \% \mathrm{C}$. Fresh, whole mulberry leaves were treated by dipping in a particular type of these solutions and then were dried by fanning. The treated leaves were fed to the worms from 3 rd to $5^{\text {th }}$ instars, 4 times in a day. The control insects were reared on mulberry leaves dipped in distilled water only.

Parameters: The growth of larvae was measured after attaining maturity, i.e., one day before spining. Fifty larvae were taken randomly from each rearing tray and then weighed individually on an electric balance. After the formation of cocoons they were harvested and cut very carefully at one end obliquely with a sharp blade to record pupal growth. The pupae were separated according to sexes. They were then individually weighed on an electric balance. The larval 
and pupal periods of the worms of various treatment groups were carefully recorded. The percentage of adult emergence was calculated by using the following formula:

$$
\text { Emergence }(\%)=\frac{\text { No. of adults emerged }}{\text { No. of larvaeused }} \times 100
$$

The Effective Rates of Rearing (\%) (ERRs\%) of $B$. mori from different concentrations of vitamins were calculated by using the following formula:

$$
\operatorname{ERR}(\%)=\frac{\text { No. of cocoon obtained }}{\text { No. of larvae taken at 3rd instar }} \times 100
$$

Statistical procedures: The data were subjected to analyses of a variance. The mean values were analyzed following Tukey's multiple comparison test (1953). The larval, pupal and larval-pupal indices were calculated following the formulae of Joshi (1985) and Prasad and Bhattacharya (1975).

\section{RESULTS AND DISCUSSION}

Larval parameter: The maximum larval weight was observed at treatment $\mathrm{T}_{2}$ $(8.7 \% \mathrm{~B}+12.5 \% \mathrm{C}$ dose combination) (Table 1$)$. In this dose combination moderate \% of vitamin $\mathrm{B}$ and $\mathrm{C}$ was used. Many researchers found that the larval characters of $B$. mori was improved by different nutrients such as ascorbic acid, folic acid, thiamin, vitamin B complex, etc. (Saha and Khan 1996, Nirwani and Kaliwal 1996, Etebari et al. 2004, Rahmathulla et al. 2007, El-Karaksy and Idris 2009).

It has been reported that Thyroxin and vitamin $\mathrm{B}_{12}$ supplemented mulberry leaves significantly increased the body weight of silkworm larvae (Majumder and Medda 1975). Saha and Khan (1997) reported that the growth B. mori larvae were significantly influenced at lower doses when the worms were reared on Sinafort ${ }^{\circledR}-\mathrm{B}$ supplemented diet. The oral supplementation of riboflavin resulted in a significant increase in larval and silkgland weight (Nirwani et al. 1996).

El-Karaksy and Idris (2009) observed that ascorbic acid significantly increased the weight of B. mori larvae and pupae. Gomaa et al. (1977) also reported that ascorbic acid significantly increased the weight of $B$. mori larvae. Several authors suggested that the enhancement in larval weight was related to phagostimulation of ascorbic acid (Singh and Reddy 1981, El-Karaksy and Idris 2009)

In higher doses of vitamin B or $\mathrm{C}$ in silkworm diet, the larval weight was considerably decreased. Saha and Khan (1996) also obtained similar results 
with cocoon characteristics. Etebari et al. (2004) demonstrated that feeding of high concentrations of ascorbic acid decreased the silkworm larval weight due to hypervitaminosis.

Table 1. Effect of vitamins $B$ and $C$ on the weight of different developmental stages of B. mori L.(gm)

\begin{tabular}{lccc}
\hline $\begin{array}{l}\text { Concentration of } \\
\text { vitamin }(\mathrm{B} \%+\mathrm{C} \%)\end{array}$ & Mature larval weight & Female pupal weight & Male pupal weight \\
\cline { 2 - 4 } $\mathrm{T}_{0}=$ Control & Mean $\pm \mathrm{SD}$ & Mean $\pm \mathrm{SD}$ & Mean $\pm \mathrm{SD}$ \\
$\mathrm{T}_{1}=2.9+25$ & $2.19 \pm 0.046^{\mathrm{b}}$ & $1.61 \pm 0.059^{\mathrm{bac}}$ & $1.26 \pm 0.040^{\mathrm{a}}$ \\
$\mathrm{T}_{2}=5.8+25$ & $3.15 \pm 0.060^{\mathrm{b}}$ & $1.62 \pm 0.015^{\mathrm{ba}}$ & $1.18 \pm 0.031^{\mathrm{bac}}$ \\
$\mathrm{T}_{3}=8.7+25$ & $3.31 \pm 0.180^{\mathrm{b}}$ & $1.53 \pm 0.038^{\mathrm{f}}$ & $1.26 \pm 0.045^{\mathrm{ba}}$ \\
$\mathrm{T}_{4}=11.6+25$ & $3.35 \pm 0.051^{\mathrm{ba}}$ & $1.53 \pm 0.021^{\mathrm{bdec}}$ & $1.18 \pm 0.031^{\mathrm{bac}}$ \\
$\mathrm{T}_{5}=2.9+12.5$ & $3.42 \pm 0.035^{\mathrm{ba}}$ & $1.57 \pm 0.030^{\mathrm{bdac}}$ & $1.17 \pm 0.012^{\mathrm{bac}}$ \\
$\mathrm{T}_{6}=5.8+12.5$ & $3.43 \pm 0.042^{\mathrm{ba}}$ & $1.58 \pm 0.042^{\mathrm{bdac}}$ & $1.18 \pm 0.025^{\mathrm{bac}}$ \\
$\mathrm{T}_{7}=8.7+12.5$ & $3.54 \pm 0.040^{\mathrm{a}}$ & $1.64 \pm 0.010^{\mathrm{a}}$ & $1.16 \pm 0.065^{\mathrm{c}}$ \\
$\mathrm{T}_{8}=11.6+12.5$ & $3.47 \pm 0.045^{\mathrm{ba}}$ & $1.63 \pm 0.042^{\mathrm{a}}$ & $1.18 \pm 0.015^{\mathrm{bac}}$ \\
$\mathrm{T}_{9}=2.9+6.25$ & $3.49 \pm 0.044^{\mathrm{ba}}$ & $1.53 \pm 0.015^{\mathrm{bdec}}$ & $1.15 \pm 0.006^{\mathrm{c}}$ \\
$\mathrm{T}_{10}=5.8+6.25$ & $3.40 \pm 0.030^{\mathrm{ba}}$ & $1.53 \pm 0.012^{\mathrm{bdec}}$ & $1.18 \pm 0.012^{\mathrm{bac}}$ \\
$\mathrm{T}_{11}=8.7+6.25$ & $3.38 \pm 0.038^{\mathrm{ba}}$ & $1.61 \pm 0.017^{\mathrm{ba}}$ & $1.18 \pm 0.026^{\mathrm{bac}}$ \\
$\mathrm{T}_{12}=11.6+6.25$ & $3.36 \pm 0.026^{\mathrm{ba}}$ & $1.58 \pm 0.006^{\mathrm{bdac}}$ & $1.17 \pm 0.010^{\mathrm{bc}}$ \\
$\mathrm{T}_{13}=2.9+3.125$ & $3.37 \pm 0.053^{\mathrm{ba}}$ & $1.51 \pm 0.021^{\mathrm{bec}}$ & $1.18 \pm 0.006^{\mathrm{bac}}$ \\
$\mathrm{T}_{14}=5.8+3.125$ & $3.32 \pm 0.047^{\mathrm{b}}$ & $1.56 \pm 0.021^{\mathrm{bdac}}$ & $1.18 \pm 0.010^{\mathrm{bac}}$ \\
$\mathrm{T}_{15}=8.7+3.125$ & $3.26 \pm 0.046^{\mathrm{b}}$ & $1.51 \pm 0.012^{\mathrm{fde}}$ & $1.17 \pm 0.006^{\mathrm{bac}}$ \\
$\mathrm{T}_{16}=11.6+3.125$ & $3.29 \pm 0.045^{\mathrm{b}}$ & $1.46 \pm 0.046^{\mathrm{be}}$ & $1.16 \pm 0.006^{\mathrm{c}}$ \\
$\mathrm{F}-$ ratio & $17.113(\mathrm{P}<0.01)$ & $11.033(\mathrm{P}<0.01)$ & $3.551(\mathrm{P}<0.01)$ \\
\hline
\end{tabular}

Note: Means followed by the same letters in a column are not significantly different by Tukey's multiple comparison test (1953).

Pupal parameter: The effect of vitamin supplementation on pupal growth of B. mori is shown in Table 1. The male and female pupal weights in different concentrations were significantly increased. Saha and Khan (1996) found that vitamins and minerals significantly increased the growth of pupae compared to the untreated controls. Citric acid supplementation increased the growth of $B$. mori pupae at lower concentrations (Khan and Saha 1996b). Khan and Faruki (1990) observed that para-amino benzoic acid supplementation had significant effects on pupal weight, length, and breadth. Fe-PLUS ${ }^{\circledR}$ supplementation significantly increased the weight of pupae when compared with the untreated controls (Khan and Saha 1996a). Thianomin ${ }^{\circledR}$ enriched mulberry leaves significantly increased the pupal weight and length in comparison to controls (Faruki 1998).

Developmental period: The results of the supplementation of vitamins on larval and pupal periods (days) obtained in the present experiments are 
presented in Table 2. It was observed that vitamin supplementation slightly reduced the larval periods in $B$. mori at lower concentrations as compared to the controls. It was also found that pupal periods significantly reduced following the supplementation. On the other hand, at some higher dose combinations slightly lengthened larval and pupal durations were obtained. It has been observed that feeding of minerals to the silkworms shortened the development periods in $B$. mori in comparison to the untreated controls (Saha and Khan 1996). Khan and Saha (2003) observed that low concentrations of thiamine significantly reduced the developmental periods of silkworm. Fe-PLUS ${ }^{\circledR}$ slightly decreased the larval and pupal periods in the treated worms but the developmental periods were increased at the higher concentrations (Khan and Saha 1996a). Nirwani et al. (1998) observed that dietary supplementation of riboflavin significantly decreased the larval period in all the treated groups.

Table 2. Effect of vitamins B and $\mathrm{C}$ on the larval, pupal and total developmental periods (days) of B. mori L.

\begin{tabular}{lccc}
\hline $\begin{array}{r}\text { Concentration of } \\
\text { vitamin }(\mathrm{B} \%+\mathrm{C} \%)\end{array}$ & Larval period & Pupal period & $\begin{array}{c}\text { Total Developmental } \\
\text { period }\end{array}$ \\
\cline { 2 - 4 } $\mathrm{T}_{0}=$ Control & $23.45 \pm 0.105(180)$ & $9.62 \pm 0.040(175)$ & 33.07 \\
$\mathrm{~T}_{1}=2.9+25$ & $23.48 \pm 0.100(185)$ & $9.61 \pm 0.050(182)$ & 33.09 \\
$\mathrm{~T}_{2}=5.8+25$ & $23.42 \pm 0.100(178)$ & $9.71 \pm 0.010(172)$ & 33.13 \\
$\mathrm{~T}_{3}=8.7+25$ & $23.29 \pm 0.100(185)$ & $9.61 \pm 0.050(180)$ & 32.9 \\
$\mathrm{~T}_{4}=11.6+25$ & $23.46 \pm 0.100(184)$ & $9.62 \pm 0.042(180)$ & 33.08 \\
$\mathrm{~T}_{5}=2.9+12.5$ & $23.42 \pm 0.100(186)$ & $9.52 \pm 0.100(185)$ & 32.94 \\
$\mathrm{~T}_{6}=5.8+12.5$ & $23.36 \pm 0.100(180)$ & $9.63 \pm 0.040(176)$ & 32.99 \\
$\mathrm{~T}_{7}=8.7+12.5$ & $23.38 \pm 0.100(178)$ & $9.70 \pm 0.015(174)$ & 33.08 \\
$\mathrm{~T}_{8}=11.6+12.5$ & $23.29 \pm 0.100(180)$ & $9.66 \pm 0.100(172)$ & 32.95 \\
$\mathrm{~T}_{9}=2.9+6.25$ & $23.32 \pm 0.100(180)$ & $9.65 \pm 0.071(172)$ & 32.97 \\
$\mathrm{~T}_{10}=5.8+6.25$ & $23.44 \pm 0.100(182)$ & $9.69 \pm 0.061(178)$ & 33.13 \\
$\mathrm{~T}_{11}=8.7+6.25$ & $23.42 \pm 0.100(186)$ & $9.68 \pm 0.100(183)$ & 33.1 \\
$\mathrm{~T}_{12}=11.6+6.25$ & $23.45 \pm 0.100(188)$ & $9.55 \pm 0.050(185)$ & 33 \\
$\mathrm{~T}_{13}=2.9+3.125$ & $23.45 \pm 0.100(188)$ & $9.56 \pm 0.051(185)$ & 33.01 \\
$\mathrm{~T}_{14}=5.8+3.125$ & $23.48 \pm 0.100(182)$ & $9.59 \pm 0.055(178)$ & 33.07 \\
$\mathrm{~T}_{15}=8.7+3.125$ & $23.35 \pm 0.100(185)$ & $9.55 \pm 0.035(180)$ & 32.9 \\
$\mathrm{~T}_{16}=11.6+3.125$ & $23.35 \pm 0.100(185)$ & $9.56 \pm 0.045(180)$ & 32.91 \\
$\mathrm{~F}-\mathrm{ratio}$ & 1.200 & $2.868(\mathrm{P}<0.01)$ & \\
\hline
\end{tabular}

*Note: No. of insects sampled.

Effective Rates of Rearing (ERRs) and adult emergence: The results of the supplementation of vitamins on the percentage of effective rates of rearing and percentage of adult emergence are shown in Table 3 . The treatments $\left(\mathrm{T}_{2}, \mathrm{~T}_{3}\right.$ and $\mathrm{T}_{4}$ ) resulted significant increase as compared to the controls. Khan and Faruki (1990) observed that low concentrations of para-amino benzoic acid produced 
detrimental effects on pupation and moth emergence. Saha and Khan (1996) observed that the effect of dietary supplementation of vitamins and minerals was to increase the ERR (\%) of B. mori. Similar results have also been recorded by Pai et al. (1988).

Table 3. Effect of vitamins $B$ and $C$ on effective rate of rearing (ERR) and adult emergence (\%) of $B$. mori L.

\begin{tabular}{lcccc}
\hline $\begin{array}{l}\text { Concentration of } \\
\text { vitamin(B\%+C\%) }\end{array}$ & ERR (\%) & $\begin{array}{c}\text { Adult emergence } \\
(\%)\end{array}$ & *d-value & $\begin{array}{c}\text { Level of } \\
\text { significance }\end{array}$ \\
\hline & 94.74 & 91.05 & -- & -- \\
$\mathrm{T}_{0}=$ Control & 97.37 & 94.74 & -1.403 & $\mathrm{NS}$ \\
$\mathrm{T}_{1}=2.9+25$ & 93.68 & 89.47 & 0.519 & $\mathrm{NS}$ \\
$\mathrm{T}_{2}=5.8+25$ & 97.37 & 98.42 & -3.261 & $\mathrm{P}<.05$ \\
$\mathrm{~T}_{3}=8.7+25$ & 96.84 & 98.42 & -3.261 & $\mathrm{P}<.05$ \\
$\mathrm{~T}_{4}=11.6+25$ & 97.89 & 96.32 & -2.124 & $\mathrm{P}<.05$ \\
$\mathrm{~T}_{5}=2.9+12.5$ & 94.74 & 90.53 & 0.175 & $\mathrm{NS}$ \\
$\mathrm{T}_{6}=5.8+12.5$ & 93.68 & 90.53 & 0.175 & $\mathrm{NS}$ \\
$\mathrm{T}_{7}=8.7+12.5$ & 94.74 & 89.47 & 0.519 & $\mathrm{NS}$ \\
$\mathrm{T}_{8}=11.6+12.5$ & 94.74 & 89.47 & 0.519 & $\mathrm{NS}$ \\
$\mathrm{T}_{9}=2.9+6.25$ & 95.79 & 92.11 & -0.372 & $\mathrm{NS}$ \\
$\mathrm{T}_{10}=5.8+6.25$ & 97.89 & 94.74 & -1.403 & $\mathrm{NS}$ \\
$\mathrm{T}_{11}=8.7+6.25$ & 98.95 & 95.79 & -1.871 & $\mathrm{NS}$ \\
$\mathrm{T}_{12}=11.6+6.25$ & 98.95 & 95.79 & -1.871 & $\mathrm{NS}$ \\
$\mathrm{T}_{13}=2.9+3.125$ & 95.79 & 92.11 & -0.372 & $\mathrm{NS}$ \\
$\mathrm{T}_{14}=5.8+3.125$ & 97.37 & 93.16 & -0.763 & $\mathrm{NS}$ \\
$\mathrm{T}_{15}=8.7+3.125$ & 97.37 & 93.68 & -0.966 & $\mathrm{NS}$ \\
\hline
\end{tabular}

Note: ${ }^{*} \mathrm{~d}=$ Standardized normal deviate.

Table 4. The growth indices of $B$. mori from various concentrations of vitamin-enriched diet

\begin{tabular}{lcccc}
\hline $\begin{array}{l}\text { Concentration of } \\
\text { vitamin }(\mathrm{B} \%+\mathrm{C} \%)\end{array}$ & $\begin{array}{c}\text { Mature larval } \\
\text { weight index }\end{array}$ & $\begin{array}{c}\text { Female pupal } \\
\text { weight index }\end{array}$ & $\begin{array}{c}\text { Male pupal weight } \\
\text { index }\end{array}$ & $\begin{array}{c}\text { Larval - pupal } \\
\text { index }\end{array}$ \\
\hline $\mathrm{T}_{0}=$ Control & 0.896552 & 1.006211 & 0.936508 & 1.000605 \\
$\mathrm{~T}_{1}=2.9+25$ & 0.987461 & 0.881988 & 1 & 1.001814 \\
$\mathrm{~T}_{2}=5.8+25$ & 1.037618 & 0.950311 & 0.936508 & 0.994859 \\
$\mathrm{~T}_{3}=8.7+25$ & 1.050157 & 0.950311 & 0.928571 & 1.000302 \\
$\mathrm{~T}_{4}=11.6+25$ & 1.0721 & 0.975155 & 0.968254 & 0.996069 \\
$\mathrm{~T}_{5}=2.9+12.5$ & 1.075235 & 0.981366 & 0.936508 & 0.997581 \\
$\mathrm{~T}_{6}=5.8+12.5$ & 1.109718 & 1.018634 & 0.920635 & 1.000302 \\
$\mathrm{~T}_{7}=8.7+12.5$ & 1.087774 & 1.012422 & 0.936508 & 0.996371 \\
$\mathrm{~T}_{8}=11.6+12.5$ & 1.094044 & 0.950311 & 0.912698 & 0.996976 \\
$\mathrm{~T}_{9}=2.9+6.25$ & 1.065831 & 0.950311 & 0.936508 & 1.001814 \\
$\mathrm{~T}_{10}=5.8+6.25$ & 1.059561 & 1 & 0.936508 & 1.000907 \\
$\mathrm{~T}_{11}=8.7+6.25$ & 1.053292 & 0.981366 & 0.928571 & 0.997883 \\
$\mathrm{~T}_{12}=11.6+6.25$ & 1.056426 & 0.937888 & 0.936508 & 0.998186 \\
$\mathrm{~T}_{13}=2.9+3.125$ & 1.040752 & 0.968944 & 0.936508 & 1 \\
$\mathrm{~T}_{14}=5.8+3.125$ & 1.021944 & 0.937888 & 0.928571 & 0.994859 \\
$\mathrm{~T}_{15}=8.7+3.125$ & 1.031348 & 0.906832 & 0.920635 & 0.995162 \\
\hline
\end{tabular}


The present findings demonstrated that vitamin B and C supplementation at lower concentrations is of importance in improving growth and development of B. mori. This would contribute to sericulture through improvement of economic traits of B. mori. However, comprehensive studies with various dose combinations are required in future works.

\section{LITERATURE CITED}

AHMED, C.A.A., CHANDRAKALA, M.V., SHIVAKUMAR, C. and RAGHURAMAN, R. 1998. Food and water utilization patterns under restricted feeding durations in Bombyx mori of pure Mysore race. J. Exp. Zool. India 1: 29-34.

EL-KARAKSY, I.A. and IDRIS, M. 2009. Ascorbic acid enhances the silk yield of the mulberry silkworm, Bombyx mori. J. Appl. Entomol. 109: 81-86.

ETEBARI, K. and MATINDOOST, L. 2004. Effects of hypervitaminosis of vitamin B on silkworm biology. J. Biosci. 29 : 417-422.

ETEBARI, K., EBADI, R. and MATINDOOST, L. 2004. Effect of feeding mulberry's enriched leaves with ascorbic acid on some biological, biochemical and economical characteristics of silkworm Bombyx mori.L. Int. J. Indus. Entomol. 8: 81-87.

FARUKI, S.I. 1998. Nutritive effects of thianomin ${ }^{\circledR}$ enriched mulberry leaves on the silkworm, Bombyx mori L. Univ. J. Zool. Rajshahi Univ. 17: 39-44.

GOMMA, A.A., EL-SHAARAWY, M.F., SALEM, Y.S. and RIZK, M.A. 1977. Effect of dietary constituents on the biology of silkworm Bombyx mori L. II. Vitamins Z. ang. Ent. 64(2): 231240

ISLAM, Z. and KHAN, A.R. 1993. Growth and development of the mulberry silkworm, Bombyx mori L. (Lepidoptera, Bombycidae) of feed supplemented with manganese sulphate. J. bio-sci. 1: 21-30.

JOSHI, K.I. 1985. Studies on growth index for Eri silkmoth, Philosamia ricini (Lepidoptera Saturniidae). Sericologia 25(3): 313-319.

KHAN, A.R. and FARUKI, S.I. 1990. Growth and development of Bombyx mori L. on feed supplemented with Para-Amino Benzoic Acid. Univ. J. Zool. Rajshahi Univ. 9 : 47-53.

KHAN, A. R. and SAHA, B. N. 1995. Growth and development of mulberry silkworm, Bombyx mori L. on feed supplemented with alanine and glutamine. Sericologia. 35(4): 657-663.

KHAN, A.R. and SAHA, B.N. 1996a. Nutritive effects of Fe-Plus(R) (Ferrous Fumarate + Folic Acid) on the silkworm, Bombyx mori L. Bangladesh.J. Zool. 24(2): 195-203.

KHAN, A.R. and SAHA, B.N. 1996b. Nutritive effects of citric acid on the mulberry silkworm . Bombyx mori L. Bull. Seric. Res. 7: 65-69.

KHAN, A.R. and SAHA, B.N. 2003. Nutritive effects of thiamine on the silkworm, Bombyx mori L. Bangladesh .J. Zool. 31(2): 169-176.

KRISHNASWAMI S. 1978. New Technology of silkworm rearing. Central Silk Board, India. 23pp

KRISHNASWAMI, S., KURNARARAJ, S.S., IJAYARAGLIAVAN, K. and KASTVISWANATHAN, K. 1971. Silkworm feeding traits for evaluating the quality of mulberry as influenced by variety, spacing and nitrogen fertilization. Indian J. Seric. 10(1): 79-90.

MAGADUM, S.B., HOOLI, M.A. and MAGADUM, V.B. 1992. Effect of application of juvenile hormone analogue in IV instar followed by thyroxine in the pure Mysore breed of Bombyx mori. (L.) Sericologia. 32(3): 385-390. 
MAJUMDAR, A.K. and MEDDA 1975. Studies on the thyrocine and Vit-B 12 induced changes in the life cycle of silkworm, India J. Physiol \& Allied Sci. 29: 1-13.

NIRWANI, R.B. and KALIWAL, B.B. 1996. Effect of Folic acid on economic traits and the change of some metabolic substances of bivoltine silkworm, Bombyx mori L. Korean J. Seric. Sci. 38 : 118-123.

NIRWANI, R.B., HUGAR, I.I. and KALIWAL, B.B. 1998. Supplementation of riboflavin on economic parameters and biochemical changes of the silkworm, Bombyx mori L. Bull. Seric. Res. 9: 37-41.

PAI, I.K., HEDGE, S.N. and KRISHNAMURTHY, N.B. 1988. PABA induced genotoxic effects in silkworm, Bombyx mori. Proc. Int. Sym. on Nature of Genotoxic Variation in Man (XII Ann Conf Of EMSI), Hyderabad, p. 54.

PRASAD, J. and BHATTACHARYA, A.K. 1975. Growth and development of SPodoPtera littoralis (LeP. Noctuidae) on several Plants. Z. Angew. Eng. 79: 34-48.

QADER, M.A., HAQUE, R. and ABSAR, N. 1994 Amino acid contents in posterior silk gland of Bombyx mori. (Bombycidae : Lepidoptera) influenced by quality of mulberry leaves. Bull. Seric. Res. 5 : 63-68.

RAHMAN, S.M. 1983. Technology of mulberry silkworm rearing suitable for the climatic condition in Bangladesh. Reshom 1,71-79.

RAHMATHULLA, V.K., DAS, P., RAMESH, M. and RAJAN, R.K. 2007. Growth rate pattern and economic traits of silkworm, Bombyx mori. L. under the influence of folic acid administration. J. Appl. Sci. Environ. Manage. 11(4): 81-84.

RAHMATHULlA, V.K., SURESH, H.M., MATHUR, V.B. and GEETHADEVI 2002. Feed conversion efficiency of Elite bivoltine CSR hybrids silkworm, Bombyx mori. L. reared under different environmental conditions. Sericologia. 42: 197-203. Ra

SAHA B.N. and KHAN, A.R. 1996. Effect of dietary supplementation of vitamins and minerals on the growth and development of Bombyx mori L. Bangladesh .J. Zool. 24(2): 125-131.

SAHA B.N. and KHAN, A.R. 1997. The nutritive effects of Sinafort( $(\mathrm{R})-\mathrm{B}$ on Bombyx mori L. Entomon 22(1): 29-34.

SAHA, A.K., RAHMAN, M.S., SAHA, B.N. and UDDIN, M. 1994. Effect of proline and leucine on the growth and development of silkworm, Bombyx mori L. Univ. J. Zool. Rajshahi Univ. 13: 75-79.

SINGH, T. and REDDY, G.P. 1981. Feeding behabiour of castor semilooper, Achoea janata Linn. To sterols, ascorbic acid and castor leaves. Indian J. Entomol. 50: 530-532.

TRIVEDY, K., REMADEVI, O.K., MAGADUM, S.B. and DATTA, R.K. 1993. Effect of Juvenile hormone analogue, Labomin on the growth and economic characters of silkworm, Bombyx mori L. Indian J. Seric. 32(2): 162-168.

TUKEY, J.W. 1953. Multiple comparisons. In: Zar, J.H. (ed.), Biostatical Analysis, 4th ed., pp 208230. Prentice Hall, USA.

VISHWANATH, A.P. and KRISHNAMURTHY, K. 1983. Effect of foliar spray on the larval development and cocoon characters of silkworm (Bombyx mori L.). Indian .J. Seric. 11/12: 1-6. 